\title{
Impact of Genetic and Climatic Factors on Parameters of Breadmaking Quality of Wheat Kernel and Flour Starch Component
}

\author{
Dragan Živančev*1 · Aleksandra Torbica² · Vojislava Momčilović ${ }^{1} \cdot$ Jasna Mastilović ${ }^{2}$ \\ ${ }^{1}$ Institute of Field and Vegetable Crops, 21000 Novi Sad, Maksima Gorkog 30, Serbia \\ 'University of Novi Sad, Institute of Food Technology, Bulevar cara Lazara 1, 21000 Novi Sad, Srbija
}

\begin{abstract}
Summary: This study investigates how genetic and climatic factors affect parameters of breadmaking quality of wheat kernel and flour starch component. Nine wheat cultivars with different combinatons of HMW-GS were grown in three production years. Various rheological devices such as Falling Number (FN), Farinograph, Amylograph, Mixolab and SDmatic were used for characterization of milled wheat samples. The most results showed that climatic factors affected parameters of breadmaking quality of wheat kernel and flour starch component more than HMW-GS composition. However, some results of the bread making quality parameters that are considered to be very reliable indicators of changes in starch component of wheat in wet years, such as FN and maximum peak of viscosity by Amylograph, were dependent of HMW-GS composition.

Key words: climatic factors, cultivars, HMW-GS, starch, wheats
\end{abstract}

\section{Introduction}

Starch is the most important polysaccharide in wheat in the form of semi-crystalline granules. Also, starch is the most abundant in wheat grain in comparison to other chemical compounds (Goesaert et al., 2005). The main starch components are two glucose polymers: amylose and amylopectin. Basically, amylose is linear molecule which is composed of D-glucopyranose units connected by $\alpha-1,4$ bond. The degree of amylose polymerization is in the range from 500 to 6000 glucose molecules. However, Shibanuma et al. (1994) proved that some fractions of amylose molecule are slightly branched due to the existence of $\alpha-1,6$ linkages. Contrary to amylose molecule, amylopectin molecule is an immense, highly branched polysaccharide. The degree of amylopectin polymerization is in the range from $3 \times 10^{5}$ to $3 \times 10^{6}$. Chains of Dglucopyranose units connected by $\alpha-1,4$ bonds are linked among themselves by $\alpha-1,6$ linkages and thus they form the amylopectin molecule (Zobel, 1988). Amylose and amylopectin ratio in wheat depends on the starch types. Usually amylose content ranges from $25 \%$ to $28 \%$, whereas amylopectin content ranges from $72 \%$ to $78 \%$

Corresponding author:

dragan.zivancev@ifvcns.ns.ac.rs

Acknowledgements:

This study was carried out within the project TR31007, financed by the Ministry of Education, Science and Technological Development of the Republic of Serbia.
(Colonna and Buléon, 1992). During dough mixing, starch absorbs $46 \%$ of water, whereas its function in dough is not fully understood (Goesaert et al., 2005). There are various hypotheses for this and Larsson and Eliasson (1997) showed that rheological properties of wheat dough depend on the specific properties surface of starch granules. Also, presence of amylolytic enzymes in wheat could be one of the reasons (Martínez-Anaya \& Jiménez, 1997), especially in the case when these are activated during preharvest sprouting, resulting in changes of physical-chemical properties of wheat starch, its partial hydrolysis and increased soluble sugars (Simsek et al., 2014).

Glutenins belong to the largest group of proteins that can be found in nature. They are the polymeric proteins linked by disulfide bonds. The genetic loci which control the synthesis of gluten proteins in wheat can be found in the first chromosome. The high molecular weight (HMW) glutenins are encoded by the Glu 1 locus of the long part of chromosome (Payne and Lawerence, 1983). Three genetically unrelated loci (Glu A1, Glu B1, and Glu D1) are located on homologous chromosomes 1A, 1B, 1D and control the synthesis of HMW glutenin subunits (GS) (Gálová et al., 2002; MacRitchie and Lafiandra 2001). In each cultivar, there can be from 3 to 5 different HMW-GS glutenin subunits encoded by the Glu A1, Glu B1, and Glu D1 loci which are usually identified according to a numerical system developed by Payne and Lawrence (1983) on the basis their electrophoretic mobility. Size of HMW-GS determined by Lab-on-a Chip electrophoretic technique $(\mathrm{LoaC})$ were in the range of 125 to $240 \mathrm{kDa}$ (Živančev et al., 2015) and their specific 
composition is one of the most important genetic factors that affect wheat quality (Payne et al., 1987a).

Also, climatic factors prevailed in some years may also have significant effect on the wheat plant development and wheat kernel development at the starch and gluten synthesis, which result in modified wheat quality. In years when wheat is exposed to daily $\mathrm{T}>35{ }^{\circ} \mathrm{C}$ without precipitation for more than five days (heat stress), it can cause dough weakling (Randall and Moss 1990), whereas values of Falling Number become higher than $400 \mathrm{~s}$ (Gooding, 2003). On the other hand, high amount of rain during spring can induce increase in protein content (Garrido-Lestache et al., 2004).

Therefore, the aim of this study was to examine how genetic and climatic factors cause changes of breadmaking quality parameters of wheat kernel and flour starch component.

\section{Material and Methods}

Nine wheat cultivars of which every third possesses different combinations of HMW-GS $(2 * 7+95+10$, null $7+92+12$ and null $7+9,5+10)$ were chosen as materials. Wheat cultivars were grown at the experimental fields of the Institute of Field and Vegetable Crops in Novi Sad (locality Rimski Šančevi, elevation - $86 \mathrm{~m}$, latitude $45^{\circ} 20^{\prime}$ and longitude $19^{\circ} 51^{\prime}$ ) in three production years (2008, 2009 and 2010). The highest amount of rainfall was recorded in 2010 from anthesis to harvest (Table 1). Duration of insolation were $2008 \approx 2009>$ 2010 whereas the mean temperature from anthesis to harvest in these three years was the lowest in May 2010 and the highest in July 2010.

The content of the sprouted kernels was determined in $100 \mathrm{~g}$ wheat samples according to EN 15587. Also, falling number (FN) was determined on wheat kernels according to Hagberg-Perten (method number 107/1, ICC 2006). The rest of the wheat samples were milled on a laboratory mill MLU 202 (Bühler, Uzwil, Switzerland) and 60\% extraction flours were examined by Brabender devices (C. W. Brabender, Duisburg, Germany) Farinograph and Amylograph (method numbers 115/ and 126/1, respectively; ICC 2006). Furthermore, parameters were evaluated with Chopin devices (Chopin, Paris, France) using Mixolab (method number 173, ICC 2011) and SDmatic.

The data were statistically analyzed by two-factorial analysis of variance (ANOVA). The first factor was the production year, whereas the second factor was the group of wheat cultivars with different combinations of HMW-GS followed by the comparison of mean values based on Tukey's multiple means comparison tests, correlation matrix (Pearson), linear regression analysis and principal component analysis (PCA). All analysis were performed by XLSTAT-Pro (demo version, Version 3.02, 2009) software.

\section{Results and Discussion}

Significant effect of the production year (Y) was found for the sprouted kernels content (SPC), falling number (FN), maximum peak of viscosity by Amylograph (AMS), water absorption by Farinograph (WA), degree of softening by Farinograph (DS), rate of starch enzymatic degradation $(\gamma)$ by Mixolab, C3-C4 by Mixolab, C5-C4 by Mixolab, and level of damage starch by Sdmatic (UCD KSDAM) $(p<0,01)$, whereas level of significance for C3 by Mixolab was at lower level $(p<0,05)$ (Table 2). The effect of the production year on these parameters was due to a high amount of rainfall in June and July of 2010 (Table 1) which caused preharvest sprouting in wheat and elevated $\alpha$-amylase activity in wheat kernels. As a result, viscosity parameters of wheat kernels and flour starch component changed. On the other hand, significant effect of group of cultivars with different combinations of HMW-GS $(G)$ was proven only for SPC, FN, AMS, DS and $\gamma$ (Table 2). The results for FN were in accordance with Denčić et al. (2013) and Barbeau et al. (2006) who found genotypic differences between groups of cultivars in $\mathrm{FN}$ values.

The results of Tukey test (Table 3) showed that FN, AMS, C3, and $\gamma$ in 2008 were statistically higher than in 2010. Contrary to these, WA, DS, C3-C4 and C5-C4 showed the opposite trend. Moreover, two of these parameters (AMS and C5-C4) showed statistical difference in all three years. The reason probably lies in the fact that in 2008 germinated kernels (Table 3)

Table 1. Weather conditions characterizing the production seasons from wheat flowering to harvest (May to July)

\begin{tabular}{|c|c|c|c|c|}
\hline Year & Month & Insolation $[\mathrm{h}]$ & Rainfall [mm] & Mean temperature $\left[{ }^{\circ} \mathrm{C}\right]$ \\
\hline \multirow{3}{*}{2008} & May & 302.6 & 40.6 & 18.3 \\
\hline & June & 293.5 & 115.9 & 21.7 \\
\hline & July & 306.5 & 41.6 & 21.7 \\
\hline \multirow{3}{*}{2009} & May & 303.4 & 50.4 & 18.4 \\
\hline & June & 249.3 & 127.2 & 19.5 \\
\hline & July & 369.8 & 58.1 & 22.8 \\
\hline \multirow{3}{*}{2010} & May & 189.5 & 113.7 & 17.0 \\
\hline & June & 226.6 & 171.8 & 20.1 \\
\hline & July & 326.1 & 99.0 & 23.1 \\
\hline
\end{tabular}


Table 2. Breadmaking quality parameters of wheat kernel and flour starch component affected by year of production and group of cultivars with different combinations of HMW-GS

\begin{tabular}{lcccccc}
\hline & DF & SPC $(\%)$ & FN $(\mathrm{s})$ & AMS $(\mathrm{BU})$ & WA $(\%)$ & DS $(\mathrm{BU})$ \\
\hline Year $(\mathrm{Y})$ & 2 & $0.600^{* *}$ & $33758^{* *}$ & $584112^{* *}$ & $95.92^{* *}$ & $3623^{* *}$ \\
Group $(\mathrm{G})$ & 2 & $0.102^{* *}$ & $23560^{* *}$ & $544545^{* *}$ & $6.19^{\mathrm{ns}}$ & $2268^{* *}$ \\
YxG & 4 & $0.04^{* *}$ & $1926^{\mathrm{ns}}$ & $87779^{* *}$ & $1.77^{\mathrm{ns}}$ & $384^{*}$ \\
Error & 18 & 0.008 & 851 & 2842 & 5.84 & 120 \\
\hline & $\mathrm{DF}$ & $\mathrm{C} 3(\mathrm{Nm})$ & $\gamma(\mathrm{Nm} / \mathrm{min})$ & $\mathrm{C} 3-\mathrm{C} 4(\mathrm{Nm})$ & $\mathrm{C} 5-\mathrm{C} 4(\mathrm{Nm})$ & $\mathrm{UCD}$ KSDAM \\
\hline Year $(\mathrm{Y})$ & 2 & $0.17^{*}$ & $0.0040^{* *}$ & $3.15^{* *}$ & $3.48^{* *}$ & $12.18^{* *}$ \\
Group $(\mathrm{G})$ & 2 & $0.04^{\mathrm{ns}}$ & $0.0015^{* *}$ & $0.11^{\mathrm{ns}}$ & $0.06^{\mathrm{ns}}$ & $0.43^{\mathrm{ns}}$ \\
YxG & 4 & $0.02^{\mathrm{ns}}$ & $0.0005^{\mathrm{ns}}$ & $0.08^{\mathrm{ns}}$ & $0.03^{\mathrm{ns}}$ & $0.84^{\mathrm{ns}}$ \\
Error & 18 & 0.04 & 0.0002 & 0.13 & 0.06 & 3.77 \\
\hline
\end{tabular}

** significant at 0.01 probability level; * significant at 0.05 probability level; ns not significant

Table 3. Mean values of breadmaking quality parameters of wheat kernel and flour starch component by the production year and different combinations of HMW-GS with differentiation by Tukey test

\begin{tabular}{|c|c|c|c|c|c|c|c|c|c|c|}
\hline & $\begin{array}{c}\text { SPC } \\
(\%)\end{array}$ & $\begin{array}{c}\mathrm{FN} \\
(\mathrm{s})\end{array}$ & $\begin{array}{c}\text { AMS } \\
(\mathrm{BU})\end{array}$ & $\begin{array}{l}\text { WA } \\
(\%)\end{array}$ & $\begin{array}{l}\mathrm{DS} \\
(\mathrm{BU})\end{array}$ & $\begin{array}{c}\mathrm{C} 3 \\
(\mathrm{Nm})\end{array}$ & $\begin{array}{c}\gamma \\
(\mathrm{Nm} / \\
\mathrm{min}) \\
\end{array}$ & $\begin{array}{r}\mathrm{C} 3-\mathrm{C} 4 \\
(\mathrm{Nm})\end{array}$ & $\begin{array}{r}\mathrm{C} 5-\mathrm{C} 4 \\
(\mathrm{Nm})\end{array}$ & $\begin{array}{l}\text { UCD } \\
\text { KSDAM }\end{array}$ \\
\hline \multicolumn{11}{|l|}{ Group } \\
\hline $2 * 7+95+10$ & $0.40^{a}$ & $331^{a}$ & $611^{\mathrm{b}}$ & $63.1^{\mathrm{a}}$ & $61.1^{\mathrm{b}}$ & $1.93^{\mathrm{a}}$ & $-0.06^{a}$ & $0.98^{\mathrm{a}}$ & $1.42^{\mathrm{a}}$ & $22.67 \mathrm{a}$ \\
\hline null $7+92+12$ & $0.31^{a}$ & $304 \mathrm{~b}$ & $732^{a}$ & $62.2^{\mathrm{a}}$ & $90.6^{a}$ & $1.86^{a}$ & $-0.05^{a}$ & $0.94 a$ & $1.33^{a}$ & $22.94^{a}$ \\
\hline null $7+95+10$ & $0.18^{\mathrm{b}}$ & $232^{\mathrm{b}}$ & $258^{c}$ & $61.4^{a}$ & $86.1^{a}$ & $1.79 \mathrm{a}$ & $-0.08^{b}$ & $0.77 \mathrm{a}$ & $1.25^{\mathrm{a}}$ & $22.51^{\mathrm{a}}$ \\
\hline \multicolumn{11}{|l|}{ Year } \\
\hline 2008 & $0.00^{\mathrm{b}}$ & $358^{a}$ & $767^{a}$ & $58.5^{\mathrm{b}}$ & $56.7^{\mathrm{b}}$ & $2.00^{a}$ & $-0.04^{a}$ & $0.24^{b}$ & $0.64^{c}$ & $21.71^{\mathrm{a}}$ \\
\hline 2009 & $0.44 a$ & $265^{a}$ & $573^{b}$ & $63.6^{\mathrm{a}}$ & $86.1^{a}$ & $1.85^{\mathrm{ab}}$ & $-0.07 \mathrm{~b}$ & $1.38^{\mathrm{a}}$ & $1.50^{\mathrm{b}}$ & $23.98^{a}$ \\
\hline 2010 & $0.45^{\mathrm{a}}$ & $243^{b}$ & $262^{c}$ & $64.6^{\mathrm{a}}$ & $95.0^{\mathrm{a}}$ & $1.73^{\mathrm{b}}$ & $-0.08^{b}$ & $1.08^{\mathrm{a}}$ & $1.85^{\mathrm{a}}$ & $22.43^{a}$ \\
\hline
\end{tabular}

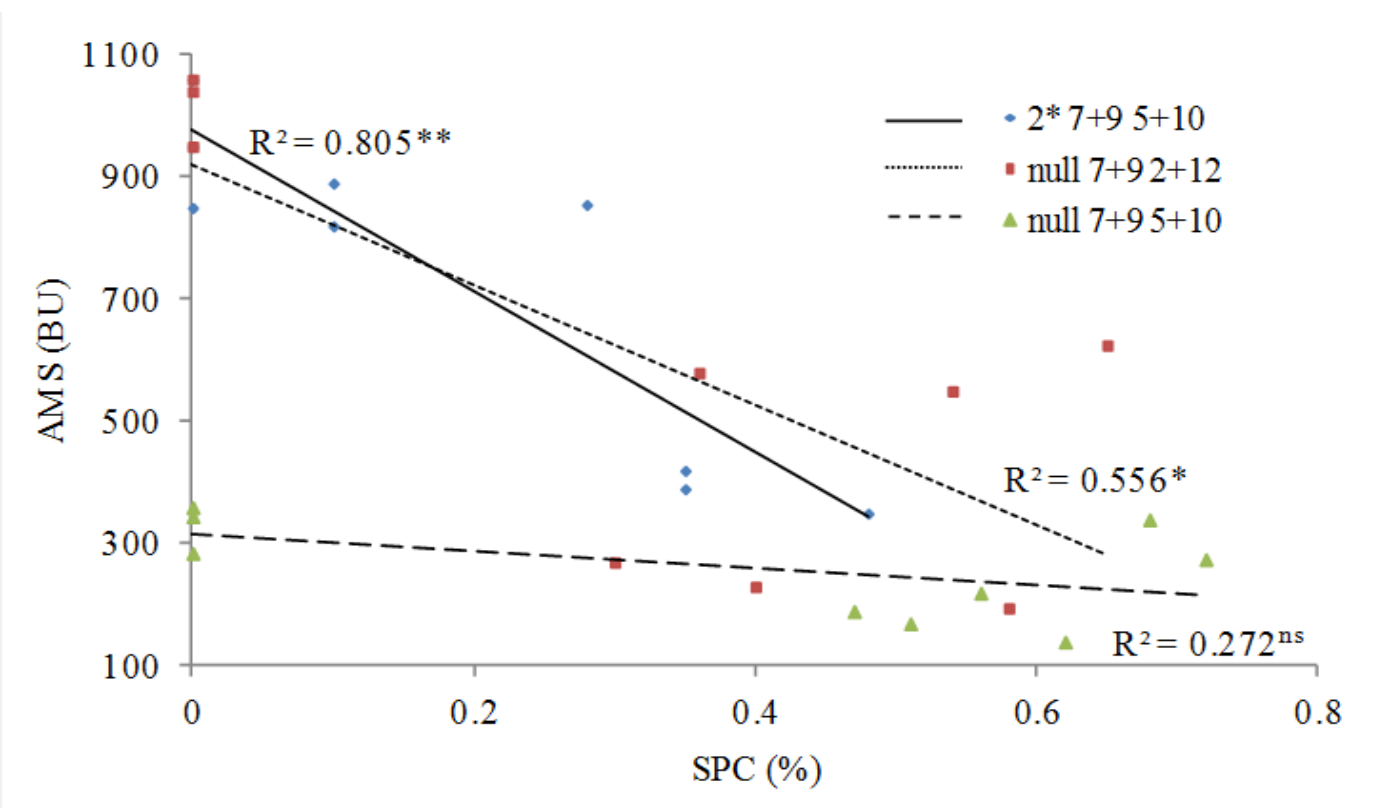

Figure 1. Linear regression analysis between AMS and SPC at wheat cultivars with different composition of HMW-GS 


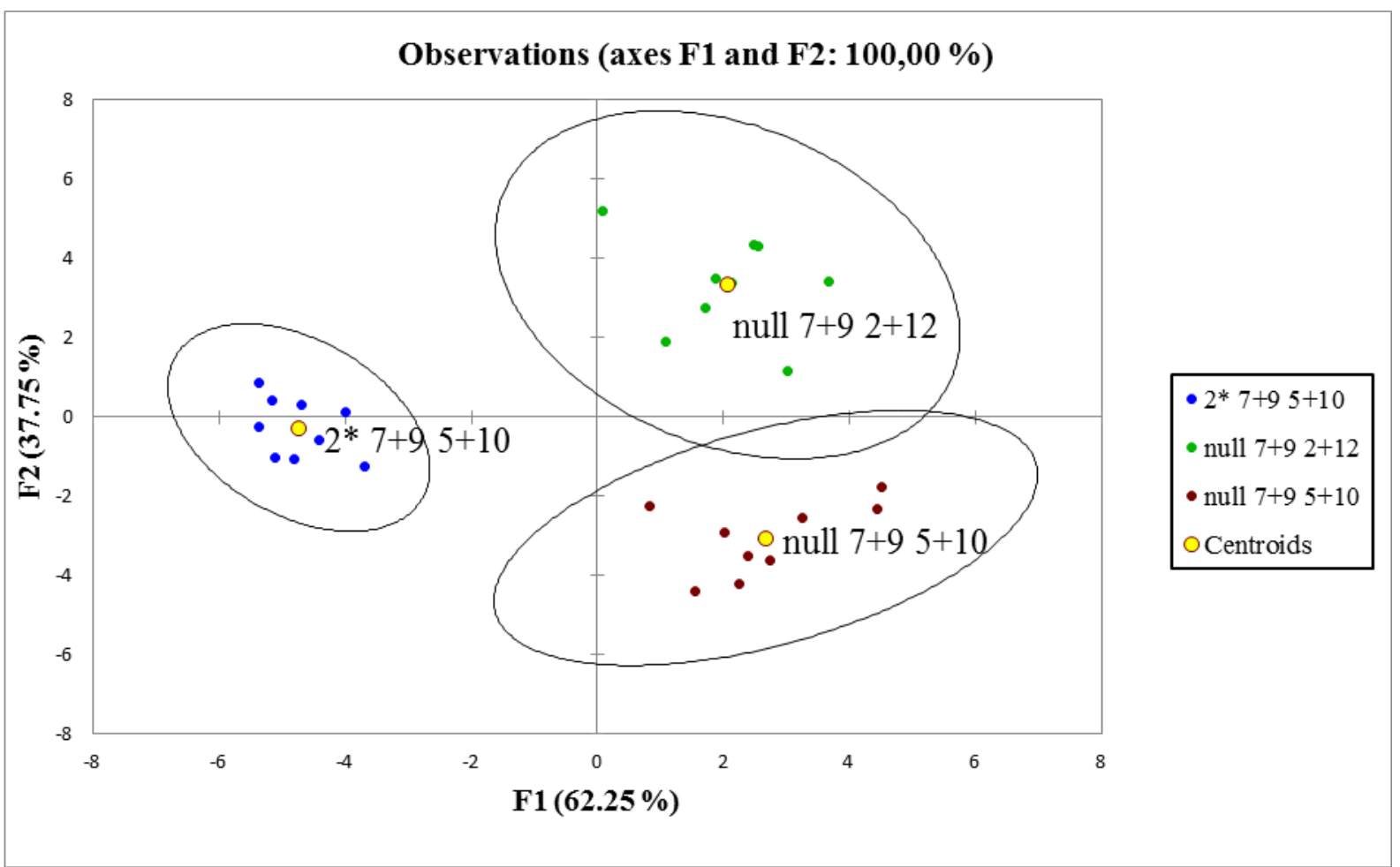

Figure 2. PCA analysis of wheat cultivars according to parameters of breadmaking quality of starch component of wheat kernel and flour

Table 4. Correlation matrix (Pearson) of breadmaking quality parameters of wheat kernel and flour starch component

\begin{tabular}{|c|c|c|c|c|c|c|c|c|c|}
\hline Variables & $\begin{array}{l}\text { SPC } \\
(\%)\end{array}$ & $\begin{array}{l}\text { FN } \\
(\mathrm{s})\end{array}$ & $\begin{array}{l}\text { AMS } \\
(\mathrm{BU})\end{array}$ & $\begin{array}{l}\text { WA } \\
(\%)\end{array}$ & $\begin{array}{c}\mathrm{DS} \\
(\mathrm{BU})\end{array}$ & $\begin{array}{c}\mathrm{C} 3 \\
(\mathrm{Nm})\end{array}$ & $\begin{array}{c}\gamma \\
(\mathrm{Nm} / \mathrm{min})\end{array}$ & $\begin{array}{c}\text { C3-C4 } \\
(\mathrm{Nm})\end{array}$ & $\begin{array}{c}\text { C5-C4 } \\
(\mathrm{Nm})\end{array}$ \\
\hline $\mathrm{FN}(\mathrm{s})$ & $-0.81 * *$ & & & & & & & & \\
\hline AMS (BU) & $-0.66^{* *}$ & $0.81^{* *}$ & & & & & & & \\
\hline WA $(\%)$ & $0.61 * *$ & $-0.45^{*}$ & $-0.38^{*}$ & & & & & & \\
\hline $\mathrm{DS}(\mathrm{BU})$ & $0.71 * *$ & $-0.78^{* *}$ & $-0.73^{* *}$ & $0.56^{* *}$ & & & & & \\
\hline C3 $(\mathrm{Nm})$ & $-0.48^{*}$ & $0.55^{* *}$ & $0.50^{* *}$ & $-0.61 * *$ & $-0.56^{* *}$ & & & & \\
\hline$\gamma(\mathrm{Nm} / \mathrm{min})$ & $-0.69 * *$ & $0.78^{* *}$ & $0.72^{* *}$ & $-0.57 * *$ & $-0.66^{* *}$ & $0.49 *$ & & & \\
\hline C3-C4 (Nm) & $0.57 * *$ & -0.32 & -0.25 & $0.44 *$ & 0.34 & -0.02 & $-0.42^{*}$ & & \\
\hline C5-C4 (Nm) & $0.68^{* *}$ & $-0.46^{*}$ & -0.29 & $0.64 * *$ & $0.49 * *$ & -0.15 & $-0.55^{* *}$ & $0.89 * *$ & \\
\hline UCD KSDAM & 0.27 & -0.13 & -0.08 & $0.53^{* *}$ & 0.33 & -0.35 & -0.27 & 0.25 & $0.39 *$ \\
\hline
\end{tabular}

** significant at 0.01 probability level; $* *$ significant at 0.05 probability level

induced by preharvest sprouting (PHS) were not detected. This was additionally confirmed by decreased trend of DS from 2008 to 2010 as an indirect measure of protease expression, which is companion of two isoforms of $\alpha$-amylase during PHS (Rall et al., 2016). Group of cultivars with combinations of HMW-GS $2 *$ $7+95+10$ and null $7+92+12$ had significantly higher values of the FN, DS, AMS and $\gamma$ in comparison to group of cultivars with subunits null $7+9$ i $5+10$ (Table 3). The result for FN is accordance with Denčić et al. (2013) who found that groups of wheat cultivars can differentiate according to $\mathrm{FN}$ values even in the productions years with wet periods.
As expected, SPC showed a statistically significant negative correlation with FN, AMS ( $\mathrm{P} \leq 0.01)$, C3 ( $\mathrm{P} \leq 0.05)$ and a positive correlation with DS $(\mathrm{P} \leq 0.01)$ (Table 4). Also, according to Table 4 SPC and Mixolab parameter $\gamma$ was negativelly corellated $(\mathrm{P} \leq 0.01)$ which indicate that increase of SPC lead to increasing of rate of starch enzymatic degradation. Moreover, SPC showed a statistically significant $(\mathrm{P} \leq 0.01)$ positive correlation between WA and parameters determined by Mixolab C3$\mathrm{C} 4$ and $\mathrm{C} 5-\mathrm{C} 4$. The result of correlation coefficient of C5C4 was in accordance with Mangan et al. (2016) who examined existence of correlation among amylase activity, $\mathrm{FN}$, mixolab parameters and baking quality. On the other 
hand, the result of correlation coefficient of C3-C4 was not in accordance with Mangan et al. (2016). The similar situation was with correlation coefficients of these parameters with FN. The only difference was that level of significance for $\mathrm{C} 5-\mathrm{C} 4$ was $\mathrm{P} \leq 0.05$, whearas in case of $\mathrm{C} 3$ -C4 there was no statistically significant correlation. Correlation coefficients among FN and AMS and C3 were expectedly positive with significance level of $\mathrm{P} \leq 0.01$, whereas in case of DS it was expectedly negative. WA had a statistically significant $(\mathrm{P} \leq 0.01)$ negative correlation with the FN and AMS, while $\gamma$ had a positive one. Similar to results of correlation coefficient between $\mathrm{FN}$ and DS, the correlation coefficient between AMS and DS and between C3 and DS was found, which inicated that proteolitic activity is a companion of amylase activity gained by the PHS, as was mentioned above. Expectedly, correlation coefficient between WA and UCD KSDAM was statistically positive $(\mathrm{P} \leq 0.01)$, since level of WA of damaged starch is very high and can vary from $200 \%$ to $430 \%$ (Barrera et al. 2007). Also, WA had a statistically significant positive correlation with the $\mathrm{C} 5-\mathrm{C} 4(\mathrm{P} \leq 0.01)$, C3-C4 $(\mathrm{P} \leq 0.05)$ and negative with $\mathrm{C} 3$ and $\gamma(\mathrm{P} \leq 0.01)$.

Additional statistical analysis by using linear regresion showed the significant relationship between SPC and AMS in group of cultivars with combinations of HMW-GS $2 * 7+95+10$ and null $7+92+12$ (Figure 1). According to Figure 1, it can be concluded that AMS values decrease as SPC values increase. Furthemore, an increase of SPC in samples of group of cultivars with null subunits $7+9$ and $5+10$ HMW-GS was also followed by a reduction of AMS values, but this effect was not significant. This indicates that AMS is dependent on this combination of HMW-GS.

PCA analysis was used to assess wheat cultivars group according to parameters of breadmaking quality of wheat kernel and flour starch component (Fig. 2). The first principal component explained $62.25 \%$ variability of data set, whereas the second principal component explained $37.75 \%$. The score plot (Fig. 2) shows that cultivars were completely separated according to their HMW-GS composition in three previously defined groups.

\section{Conclusions}

Based on the results of two-factorial ANOVA, it could be concluded that climatic factors that prevailed in 2008, 2009, and 2010 affected parameters of breadmaking quality of wheat kernel and flour starch component more than HMW-GS composition of the examined wheat cultivars. Also, this confirmed the results of Tukey test. However, ANOVA showed that some parameters of bread making quality that are considered to be very reliable indicators of changes in starch component of wheat in wet years, such as FN and AMS, were dependent on HMW-GS composition. Additionally, this was confirmed throughout the linear regresion where there was no significant relationship between SPC and AMS at samples of group of cultivars with null subunits $7+9$ and $5+10$ HMW-GS. Furthermore, PCA analysis of breadmaking quality parameters of wheat kernel and flour starch component completely separated wheat cultivars according to their HMW-GS composition.

\section{References}

Barbeau, W.E., Griffey, C.A. \& Yan, Z. (2006). Evidence that minor sprout damage can lead to significant reductions in gluten strength of winter wheat. Cereal Chemistry. 83, 306-310.

Barrera, G.N., Pérez, G.T., Ribotta, P.D., \& León, A.L. (2007). Influence of damaged starch on cookie and bread-making quality. Euroepan Food Research and Technology, 225, 1-7.

Colonna, P., \& Buléon, A. (1992). New insights on starch structure and properties. Paper presented at the Cereal chemistry and technology: A long past and a bright future, Proceedings of the Ninth International Cereal and Bread Congress.

Dencic, S., DePauw, R., Kobiliski, B., \& Momcilovic V. (2013). Hagberg falling number and rheological properties of wheat cultivars in wet and dry preharvest periods, Plant Production Science, 16(4), 342-351

European Standard (2008). EN 15587:2008. Cereals and cereal products - Determination of Besatz in wheat (Triticum aestivum L.), durum wheat (Triticum durum Desf.), rye (Secale cereale L.) and feed barley (Hordeum vulgare L.). Brussels: European Committee for Standardization.

Gálová, Z., Michalik, I., Knoblochova, H., \& Gregova, E. (2002). Variation in HMW glutenin subunits of different species of wheat. Rostilinna Vyroba, 48, 15-19.

Garrido-Lestache, E., López-Bellido, R. J., \& López-Bellido, L. (2004). Effect of $\mathrm{N}$ rate, timing and splitting and $\mathrm{N}$ type on bread-making quality in hard red spring wheat under rainfed Mediterranean conditions. Field Crops Research, 85(2-3), 213-236.

Goesaert, H., Brijs, K., Veraverbeke, W. S., Courtin, C. M., Gebruers, K., \& Delcour, J. A. (2005). Wheat flour constituents: how they impact bread quality, and how to impact their functionality. Trends in Food Science \& Technology, 16, 12-30.

Gooding, M. J., Ellis, R. H., Shewry, P. R., \& Schofield, J. D. (2003). Effects of restricted water availability and increased temperature on the grain filling, drying and quality of winter wheat. Journal of Cereal Science, 37(3), 295-309.

International Association for Cereal Science and Technology (2011). ICC standard method 173. ICC: Vienna, Austria.

International Association for Cereal Science and Technology. (2006). ICC standard methods 107/1, 114/1, and 126/1: 2006. ICC: Vienna, Austria.

Larsson, H., \& Eliasson, A.-C. (1997). Influence of the starch granule surface on the rheological behaviour of wheat flour dough. Journal of Texture Studies, 28, 487-501.

MacRitchie, F., \& Lafiandra, D. (2001). The use of near-isogenic wheat lines to determine protein composition-functionality relationship. Cereal Chemistry, 78(5), 501-506.

Mangan, D., Szafranska, A., McKie, V., \& McCleary B. V. (2016) Investigation into the use of the amylase SD assay of milled wheat extracts as a predictor of baked bread quality. Journal of Cereal Science, 70, 240-246.

Martínez-Anaya, M. A., \& Jiménez, T. (1997). Functionality of enzymes that hydrolyse starch and non-starch polysaccharide in breadmaking. Zeitschrift fur Lebensmittel- Untersuchung und Forschung, 205, 209-214.

Payne, P. I., \& Lawerence, G. J. (1983). Catalogue of alleles for the complex gene loci, Glu-A1, Glu-B1, Glu-D1 which code for high-molecular-weight subunits of glutenin in hexaploid wheat. Cereal Research Communications, 11, 29-35.

Payne, P. I., Nightingale, M. A., Krattiger, A. F., \& Holt, L. M. (1987). The relationship between HMW glutenin subunit composition and the bread-making quality of British-grown wheat varieties. Journal of the Science of Food and Agriculture, 40(1), 51-65. 
Randall, P. J., \& Moss, H. J. (1990). Some effects of temperature regime during grain filling on wheat quality. Australian Journal of Agricultural Research, 41, 603-617.

Shibanuma, K., Takeda, Y., Hizukuri, S., \& Shibata, S. (1994). Molecularstructures of some wheat starches. Carbohydrate Polymers, 25, 111-116.

Simsek, S., Ohm, J.-B., Lu, H., Rugg, M., Berzonsky, W., Alamri, M., \& Mergoum, M. (2014). Effect of pre-harvest sprouting on physicochemical properties of starch in wheat. Foods, 3(2), 194-207.
Živančev, D., Horvat, D., Torbica, A., Belović., M., Šimić, G., Magdić, D., \& Đukić, N. (2015) Benefits and limitations of Labon-a-Chip method over Reversed-Phase High-Performance Liquid Chromatography method in gluten proteins evaluation. Journal of Chemistry, Volume 2015, Article ID 430328, 9 pages http://dx.doi.org/10.1155/2015/430328

Zobel, H. F. (1988). Starch crystal transformations and their industrial importance. Starch/Stärcke, 40, 1-7.

\section{Uticaj genetskih i klimatskih faktora na pokazatelje tehnološkog kvaliteta skrobne komponente pšeničnog zrna i brašna}

\section{Dragan Živančev · Aleksandra Torbica · Vojislava Momčilović · Jasna Mastilović}

Sažetak: Cilj ovog rada je bio da se ispita kakve promene na pokazateljima tehnološkog kvaliteta skrobne komponente pšeničnog zrna i brašna imaju genetski i klimatski faktori. Devet sorti pšenice različitih kombinacija HMW-GS proizvedenih u tri različite godine uzeti su kao materijal za istraživanje. Na različitim reološkim uređajima poput Perten-ovog broja padanja, Farinografa, Amilografa, Mixolab-a i SDmatic urađena je karakterizacija samlevenih pšeničnih uzoraka. Većina rezultata pokazala je da klimatski faktori izazivaju veće promene na tehnološkom kvalitetu skrobne komponente pšeničnog zrna i brašna nego HMW-GS sastav. Sa druge strane, neki pokazatelji tehnološkog kvaliteta koji se smatraju veoma pouzdanim indikatorima promena na skrobnoj komponenti pšenice u godinama sa velikom količinom padavina, poput broja padanja i maksimalnog viskoziteta na amilografu, ipak su zavisili od HMW-GS sastava.

Ključne reči: HMW-GS, klimatski faktori, pšenica, skrob, sorta 